\title{
Antiurolithiasis, Antioxidant, Anti-inflammatory, Analgesic, and Diuretic Activity of Ethanolic Extract of Seeds of Caesalpinia bonducella
}

\author{
Ajay Kumar ${ }^{1,3}$, Manmath Kumar Nandi ${ }^{2}$, Brijesh Kumar ${ }^{1, *}$, Ashutosh Kumar ${ }^{1}$, Rajesh Kumar ${ }^{1}$, Ambrish Kumar Singh ${ }^{3}$, Manish Singh ${ }^{1}$ \\ 'Department of Pharmacology, Institute of Medical Science, Banaras Hindu University, Varanasi, Uttar Pradesh, INDIA. \\ 2Department of Medicinal Chemistry, Faculty of Ayurveda, Institute of Medical Sciences, Banaras Hindu University, Varanasi, Uttar Pradesh, INDIA. \\ 3Pharmacy Ayurveda, Institute of Medical Sciences, Rajiv Gandhi South Campus, Banaras Hindu University, Barkachha, Mirzapur, Uttar Pradesh, INDIA
}

\begin{abstract}
Background: Urolithiasis, commonly known as nephrolithiasis, kidney stone, or renal stone, is a disorder caused by a decrease in anti-oxidant capability, damaged renal epithelium or consistently supersaturated urine, which leads to increased crystallisation. The aim of this study was to evaluate antiurolithiatic, antioxidant, analgesic, anti-inflammatory and diuretic property of ethanolic extract of $C$. bonducella seeds (EECB). Methods: For the probable molecules in EECB, GC-MS analysis was performed. Antioxidant property was investigated using DPPH and FRAP assays. Nucleation and aggregation assays were used for in vitro urolithiatic study. The diuretic, anti-inflammatory and analgesic activity were performed in animal model. Results: GC-MS analysis of EECB identified the presence of Vitamin E, steroidal ring containing compounds and hydrocarbons. EECB was found to be effective in scavenging free radicals. EECB exhibited significant inhibition of nucleation and aggregation of calcium oxalate crystals. The anti-inflammatory and analgesic activity of EECB were found to be significant effective at dose of $400 \mathrm{mg} / \mathrm{kg}$. Further, EECB exhibited a significant increase in urinary output and electrolytes $\mathrm{Na}^{+}, \mathrm{Cl}^{-}$excretion at dose of $400 \mathrm{mg} / \mathrm{kg}$. Conclusion: The finding of this study suggested that EECB possess
\end{abstract}

significant pharmacological activities like antioxidant, anti-inflammatory, analgesic, diuretic, and antiurolithiatic activities. Antioxidants property of EECB could be used in preventing oxidative stress; the anti-inflammatory and analgesic properties could be used in the prevention of inflammation and pain of damaged epithelial cells of nephrons, which are caused by intra-papillary calcifications; the diuretic activity could be used in reducing supersaturation of calcium oxalate.

Key word: Urolithiasis, Calcium oxalate crystal, Nucleation, Aggregation, GC-MS.

\section{Correspondence}

Brijesh Kumar,

Department of Pharmacology, Faculty of Modern Medicine, Institute of Medical Sciences, Banaras Hindu, Varanasi-221005, Uttar Pradesh, INDIA.

Email id: asthwal@rediffmail.com

DOI: 10.5530/ijpi.2021.3.54

\section{INTRODUCTION}

Urolithiasis also termed as nephrolithiasis, kidney stone, or renal stone and is one of the most prevalent urologic diseases in Asia. There are two types of stone found in urolithiasis. The first one is calcareous stone including calcium oxalate and calcium phosphate; and the second is non-calcareous stone including uric acid, struvite (infection stone by protease bacteria), cystine, uric acid stones. In kidney stones, over $80 \%$ cases of calcium oxalate, 5-10\% of uric acid stone, $6 \%-13 \%$ of calcium phosphate, $2 \%-15 \%$ of struvite (infectious stone), $1 \%$ of apatite, and $0.5 \%-1 \%$ of cystine are found in the world. ${ }^{1-3}$

In Ayurveda, many herbal plants have been used as antiurolithiasis drug. ${ }^{2,4}$ Caesalpinia bonducella L (Family: Fabaceae), commonly known as Nata Karanja, Karanj, Kala Karanja (in Hindi), is abundant in the tropical and subtropical regions. The C. bonducella is extensively used in folk medicines ${ }^{5}$ for the treatment of filarial infection, common cold, tumor, fever, asthma, dysentery, and diabetes in India and China. ${ }^{5-7}$ The extract of leaves, seeds and seeds kernel of $C$. bonducella have been studied for antitumor activity, ${ }^{8}$ anti-inflammatory effects, ${ }^{7}$ an increase of contractile force, ${ }^{9}$ contractile activity of uterine smooth muscle, ${ }^{10}$ antioxidants, ${ }^{6,8}$ and antihyperglycemic. ${ }^{6}$ No study has been reported antiurolithiatic effect of $C$. bonducella seed. The purpose of this study is to scientifically justify antiurolithiatic property of ethanolic extract of seed of C. bonducella.

\section{MATERIALS AND METHODS}

\section{Plant material and extraction}

The seeds of C. bonducella were collected from Varanasi, India and identified by Dr. Ashwani K. Kushwaha, Department of Dravya Guna, Faculty of Ayurveda, IMS, BHU, Varanasi. The air-dried, powdered seeds of C. bonducella $(100 \mathrm{~g}$ ) were soaked with $1 \mathrm{~L}$ of $95 \%$ ethanol for 7 days. The crude extract was obtained by filtration through filter paper. The filtrate was evaporated by rotatory evaporator to give a viscous brownish dark mass. ${ }^{11}$

\section{GC-MS analysis}

GC-MS analysis of EECB was performed at Advance CIF, JNU, Delhi, India, on an instrument Shimadzu QP-2010 Plus TDS TD 20.

\section{Antioxidant activity}

DPPH assay: $7.89 \mathrm{mg}$ of DPPH was dissolved in $100 \mathrm{ml} 99.5 \%$ ethanol to make $0.2 \mathrm{mmol} / \mathrm{L}$ DPPH solution and incubated in dark for $2 \mathrm{hr}$. The EECB at various concentrations $(25,50,100$, and $200 \mu \mathrm{g} / \mathrm{ml})$ were diluted with ethanol to get testing sample solution. $200 \mu \mathrm{l}$ of EECB, $1 \mathrm{ml}$ of DPPH solution and $800 \mu \mathrm{l}$ of Tris- $\mathrm{HCl}$ buffer $(\mathrm{pH}$ 7.4) were mixed in test tube and kept at $25^{\circ} \mathrm{C}$ for $45 \mathrm{~min}$. The absorbance was recorded at $517 \mathrm{~nm}$ by UV-Visible spectrophotometric (Systronics Double Beam UV-VIS Spectrophotometer: 2202). The blank was prepared by mixing 
$1.2 \mathrm{ml}$ of ethanol and $0.8 \mu \mathrm{l}$ of Tris- $\mathrm{HCl}$ buffer $(\mathrm{pH}$ 7.4). The DPPH reagent without sample was used as control and ascorbic acid (2 to $20 \mu \mathrm{g} / \mathrm{ml}$ ) as standard. ${ }^{12-15}$

$$
\% \text { scavenging of DPPH free radicals }=\left[1-\left(\mathrm{A}_{\mathrm{t}} / \mathrm{A}_{\mathrm{c}}\right)\right] \times 100
$$

where $A_{c}$ is the absorbance of control and $A_{t}$ is the absorbance of test sample.

Ferric Reducing Antioxidant Power (FRAP) assay: EECB was analysed at concentrations of 25,50,100, and $200 \mu \mathrm{g} / \mathrm{ml} .100 \mathrm{ml}$ of $\mathrm{FeCl}_{3}$ solution ( $0.02 \mathrm{~mol} / \mathrm{L}), 10 \mathrm{ml}$ of $\mathrm{pH} 3.6$ Acetic acid buffer $(0.3 \mathrm{~mol} / \mathrm{L})$, and $10 \mathrm{ml}$ of TPTZ solution $(0.01 \mathrm{~mol} / \mathrm{L})$ were mixed to prepare fresh FRAP reagent. $0.2 \mathrm{ml}$ of EECB was added in test tubes and mixed with $18 \mu \mathrm{l}$ of FRAP reagent. The test tube was incubated at $40^{\circ} \mathrm{C}$ for $1 \mathrm{~h}$. The OD at $593 \mathrm{~nm}$ was measured. The FRAP reagent without sample was used as control and ascorbic acid ( 2 to $20 \mu \mathrm{g} / \mathrm{ml}$ ) as standard. The antioxidant power calculated by the following formula: ${ }^{12-14,16}$

$$
\% \text { FRAP }=\left[1-\left(A_{t} / A_{c}\right)\right] \times 100
$$

where $A_{c}$ is the absorbance of control and $A_{t}$ is the absorbance of test sample.

\section{In vitro Urolithiatic activity}

Nucleation assay: Buffer ( $\mathrm{pH}$ 6.5) containing Tris $50 \mathrm{mmol} / \mathrm{L}$ and sodium chloride $150 \mathrm{mmol} / \mathrm{L}$ were used as solvent to prepare $\mathrm{CaCl}_{2}(5 \mathrm{mmol} / \mathrm{L})$ and $\mathrm{Na}_{2} \mathrm{C}_{2} \mathrm{O}_{4}(7.5 \mathrm{mmol} / \mathrm{L})$ and the temperature was maintained at $37^{\circ} \mathrm{C}$ during the entire experiment. A calcium chloride solution of $9.5 \mathrm{ml}$ was mixed with $2 \mathrm{~mL}$ of EECB (at concentrations of $10-1000 \mu \mathrm{g} / \mathrm{ml}$ ). Nucleation was initiated by adding $9.5 \mathrm{~mL} \mathrm{Na}_{2} \mathrm{C}_{2} \mathrm{O}_{4}(7.5 \mathrm{mmol} / \mathrm{L})$. Final solutions were incubated for $60 \mathrm{~min}$ at $37^{\circ} \mathrm{C}$. The distilled water was used as blank and cystone as a standard. The optical density (OD) was taken at $620 \mathrm{~nm}$ by a UV-Visible spectrophotometer. ${ }^{17-19}$

$\%$ inhibition of nucleation $(\% \mathrm{IN})=\left[1-\left(\mathrm{OD}_{\text {sample }} / \mathrm{OD}_{\text {control }}\right)\right] \times 100$

Where $\mathrm{OD}_{\text {sample }}$ is the optical density of EECB or cystone, $\mathrm{OD}_{\text {control }}$ is optical density without EECB or cystone

Aggregation assay: The crystals of calcium oxalate were prepared by adding equal volume of $\mathrm{CaCl}_{2}$ and $\mathrm{Na}_{2} \mathrm{C}_{2} \mathrm{O}_{4}$ at $0.1 \mathrm{~mol} / \mathrm{L}$; heated up to $60^{\circ} \mathrm{C}$ for $3 \mathrm{hr}$ and allowed to stand overnight at $37^{\circ} \mathrm{C}$. The calcium oxalate crystals were separated by centrifugation at $2000 \mathrm{rpm}$ and dried at room temperature. Buffer ( $\mathrm{pH} 6.5$ ) containing Tris $50 \mathrm{mmol} / \mathrm{L}$ and sodium chloride $150 \mathrm{mmol} / \mathrm{L}$ were used as solvent to prepare $0.75 \mathrm{mg} / \mathrm{ml}$ calcium oxalate crystals. $9 \mathrm{ml}$ of calcium oxalate crystals solution was mixed with $1 \mathrm{ml}$ of EECB (at concentrations of $10-1000 \mu \mathrm{g} / \mathrm{ml}$ ) and incubated for $60 \mathrm{~min}$ at $37^{\circ} \mathrm{C}$. The distilled water was used as blank and cystone as a standard. The OD was taken at $620 \mathrm{~nm}$ by a UV-Visible spectrophotometer. ${ }^{17-19}$

$$
\% \mathrm{AI}(\text { aggregation inhibition })=\left[1-\left(\mathrm{OD}_{\text {sample }} / \mathrm{OD}_{\text {control }}\right)\right] \times 100
$$

Where $\mathrm{OD}_{\text {sample }}$ is optical density with EECB or cystone, $\mathrm{OD}_{\text {control }}$ is optical density without EECB or cystone

\section{Analgesic Activity}

Animals: Healthy Wistar albino rats (120-160 g) of either sex and approximately 8-12 weeks old, were used in the study. The animals were divided into 4 groups $(n=5)$. All experiments were conducted according to the guideline and approved by the ethics committee of IMS, BHU, Varanasi, India (2211, 07.11.2020).

Writhing Test: Normal control group (Group I) received p.o. vehicle (0.5\% CMC). Standard drug diclofenac sodium (10 mg/kg) was administered p.o in Group II, while 200 and $400 \mathrm{mg} / \mathrm{kg}$ of EECB were administered p.o. in groups III and IV, respectively. After 30 min of dosing, $0.1 \mathrm{ml}$ of acetic acid $(0.6 \% \mathrm{v} / \mathrm{v})$ as irritant was injected intraperitoneal and the number of writhes (stretching of the abdomen, twisting of the trunk, contractive movements of abdomen, stretching of one or two hind limb, extension of body) was counted from 5 to $30 \mathrm{~min} .{ }^{20-22}$

Formalin Test: Normal control group (Group I) received p.o. vehicle (0.5\% CMC). Standard drug morphine $(5 \mathrm{mg} / \mathrm{kg}$ ) was administered p.o in Group II, while 200 and $400 \mathrm{mg} / \mathrm{kg}$ of EECB were administered p.o. in groups III and IV, respectively. After $30 \mathrm{~min}$ of dosing, $0.05 \mathrm{ml}$ formalin $(10 \% \mathrm{v} / \mathrm{v})$ as irritant was injected into the dorsal portion of the front paw. The total time spent in licking and biting of the irritant injected paw were recorded on stopwatch in early phase (1-5 min) considered as neurogenic phase and in late phase (15-30 $\mathrm{min})$ considered as inflammatory phase..$^{20,21,23}$

Hot Plate Test: Normal control group (Group I) received p.o. vehicle (0.5\% CMC). Standard drug morphine $(5 \mathrm{mg} / \mathrm{kg}$ ) was administered p.o in Group II, while 200 and $400 \mathrm{mg} / \mathrm{kg}$ of EECB were administered p.o. in groups III and IV, respectively. The surface of analgesio-meter was maintained at temperature $55 \pm 1^{\circ} \mathrm{C}$ and 15 seconds cut-off time. After 30,60 , and 90 min of dosing, the animals were placed on analgesio-meter (Techno Eddy's hot plate) and the time was recorded between placement and licking, bitting, or withdrawal of the hind paws. ${ }^{21,23}$

Tail Flick Test: Normal control group (Group I) received p.o. vehicle (0.5\% CMC). Standard drug morphine ( $5 \mathrm{mg} / \mathrm{kg}$ ) was administered p.o in Group II, while 200 and $400 \mathrm{mg} / \mathrm{kg}$ of EECB were administered p.o. in groups III and IV, respectively. After 5, 15, 30, 60, and 90 min of dosing, the tip of the rat's tail (last $3 \mathrm{~cm}$ ) was placed on the radiant heat source (Techno analgesio-meter) and the time was recorded between placement and removal of tail with the cut-off time of 15 seconds (to avoid tail injury)..$^{21,23}$

\section{Anti-inflammatory activity}

Carrageenan model: Normal control group (Group I) received p.o. vehicle (0.5\% CMC). Standard drug indomethacin $(20 \mathrm{mg} / \mathrm{kg})$ was administered p.o in Group II, while 200 and $400 \mathrm{mg} / \mathrm{kg}$ of EECB were administered p.o. in groups III and IV, respectively. After $60 \mathrm{~min}$ of dosing, $0.1 \mathrm{ml}$ of $1 \% \mathrm{w} / \mathrm{v}$ carrageenan was given subcutaneously (s.c.) into the plantar surface of the hind paw of rats. Paw edema was measured by plethysmometer at $0 \mathrm{~min}, 1 \mathrm{~h}, 2 \mathrm{hr}, 3 \mathrm{hr}$, and $4 \mathrm{hr}^{20,21}$

Formalin model: Normal control group (Group I) received p.o. vehicle (0.5\% CMC). Standard drug indomethacin $(20 \mathrm{mg} / \mathrm{kg})$ was administered p.o in Group II, while 200 and $400 \mathrm{mg} / \mathrm{kg}$ of EECB were administered p.o. in groups III and IV, respectively. After $60 \mathrm{~min}$ of dosing, $0.1 \mathrm{ml}$ of $1 \%$ formalin was given s.c. into the plantar surface of the hind paw of rats. Paw edema was measured by plethysmometer at $0 \mathrm{~min}, 1 \mathrm{hr}, 2 \mathrm{hr}$, $3 \mathrm{hr}$, and $4 \mathrm{hr} .^{21}$

Egg albumin model: Normal control group (Group I) received p.o. vehicle (0.5\% CMC). Standard drug indomethacin $(20 \mathrm{mg} / \mathrm{kg})$ was administered p.o in Group II, while 200 and $400 \mathrm{mg} / \mathrm{kg}$ of EECB were administered p.o. in groups III and IV, respectively. After $60 \mathrm{~min}$ of dosing, $0.1 \mathrm{ml}$ of egg albumin was given s.c. into the plantar surface of the hind paw of rats. Paw edema was measured by plethysmometer at $0 \mathrm{~min}, 1 \mathrm{hr}, 2 \mathrm{hr}$, $3 \mathrm{hr}$, and $4 \mathrm{hr} .^{21}$

\section{Diuretic activity in rats}

Twenty-five (25) healthy Wistar albino rats were divided into five groups $(n=5)$. All rats received $0.9 \%$ Sodium chloride $(25 \mathrm{ml} / \mathrm{kg})$ to maintain uniform water and salt load. Normal control group (Group I) received p.o. vehicle (0.5\% CMC). Standard drug furosemide $(10 \mathrm{mg} / \mathrm{kg})$ was administered p.o in Group II, while 200 and $400 \mathrm{mg} / \mathrm{kg}$ of EECB were administered p.o. in groups III and IV, respectively. After dosing, the rats 
were placed in metabolic cage for the urine collection at every hour up to $5 \mathrm{hr}$. Total urine volume and urinary concentration of $\mathrm{Na}^{+}, \mathrm{K}^{+}$, and $\mathrm{Cl}^{-}$were measured. ${ }^{24,25}$

\section{Statistical analysis}

The data were expressed as mean \pm SEM and analysed by GraphPad Prism version 8.0.2 software. Ordinary one-way and two-way ANOVA with Dunnett's multiple comparisons test was applied.

\section{RESULTS}

The identified constituents of EECB by GC-MS was given in Table 1. The results were revealed that the scavenging of the free radicals was found to be effective and concentration-dependent for EECB in DPPH and FRAP assays. The $\mathrm{IC}_{50}$ of ascorbic acid was 7.36 and $7.85 \mu \mathrm{g} / \mathrm{ml}$ while that of EECB was 95.32 and $153.13 \mu \mathrm{g} / \mathrm{ml}$ in DPPH and FRAP assays, respectively. The ascorbic acid equivalent $\mathrm{mg} / \mathrm{g}$ dry weight extract was 77.24 and 51.23 AA E mg/g DW extract in DPPH and FRAP assays, respectively.

The effect of EECB on nucleation and aggregation at different concentrations of EECB is presented in Figure $1 \mathrm{~A}$ and $1 \mathrm{~B}$. Figure $2 \mathrm{~B}, 4 \mathrm{C}, 4 \mathrm{D}$ and $4 \mathrm{E}$ showed that minimum number and the smallest size of crystals were seen with both EECB and cystone as compared with control (Figure 4A).
Pre-treatment with EECB (200 and $400 \mathrm{mg} / \mathrm{kg}$ ) showed a significant analgesic potential in the tail-flick model (Figure $3 \mathrm{~A}$ ). EECB at dose of $400 \mathrm{mg} / \mathrm{kg}$ increased significantly $(P<0.05$ to $P<0.0001)$ an anti-nociceptive effect as compared with the normal control group. The Eddy's hot plate results in Figure 3B showed that EECB (200 and $400 \mathrm{mg} / \mathrm{kg}$ ) significantly $(P<0.05$ to $P<0.0001)$ enhanced response time (latency) as compared with normal control group. Anti-nociceptive effects of the EECB using acetic acid-induced writhing model are showed in Figure 3C. EECB decreased pain significantly $(P<0.01$ to $P<0.0001)$ as comparison with the normal control group. In formalin model, the analgesic potential of EECB is presented in Figure 3D. In phase I and phase II, EECB reduced pain significantly $(P<0.01)$ at $400 \mathrm{mg} / \mathrm{kg}$ dose in both phase as compared with the normal control group.

As shown in Figure 4A, 4B, and 4C, EECB ( $400 \mathrm{mg} / \mathrm{kg}$ ) showed a significant $(P<0.05$ to $P<0.0001)$ inhibition of paw edema in carrageenan, formalin, and egg albumin model as compared with normal control group. In carrageenan and formalin-induced edema, EECB at dose of $200 \mathrm{mg} / \mathrm{kg}$ showed a significant $(P<0.05$ to $P<0.0001)$ inhibition of edema at $2 \mathrm{hr}$ and $3 \mathrm{~h}$ while, in egg albumin, $200 \mathrm{mg} / \mathrm{kg}$ caused a significant $(P<0.01)$ inhibition of edema at $2 \mathrm{hr}$ in comparison to normal control group.

EECB at dose of $200 \mathrm{mg} / \mathrm{kg}$ showed a significant $(P<0.01)$ increase in urine output in $3 \mathrm{~h}$ to $5 \mathrm{~h}$ and $400 \mathrm{mg} / \mathrm{kg}$ dose of EECB showed a significant $(P<0.001$ to $P<0.0001)$ increase in urine output in $2 \mathrm{hr}$ to $5 \mathrm{hr}$

Table 1: List of major identified constituents of ethanolic C. bonducella extract in GC-MS analysis.

\begin{tabular}{|c|c|c|c|c|c|}
\hline S.N. & Peak & R. Time & Area & $\%$ Area & Chemical name \\
\hline 1 & 1 & 6.958 & 7831055 & 1.05 & 5-Hydroxymethylfurfural \\
\hline 2 & 4 & 11.835 & 60214169 & 8.09 & 1,3-Propanediol, 2-ethyl-2-(hydroxymethyl) \\
\hline 3 & 6 & 15.678 & 172473960 & 23.18 & 4-O-Methylmannose \\
\hline 4 & 8 & 16.389 & 23159181 & 3.11 & n-Hexadecanoic acid \\
\hline 5 & 12 & 18.081 & 73027827 & 9.82 & 10(E),12(Z)-Conjugated linoleic acid \\
\hline 6 & 13 & 18.123 & 22544898 & 3.03 & cis-Vaccenic acid \\
\hline 7 & 31 & 21.228 & 8382836 & 1.13 & Octacosane \\
\hline 8 & 42 & 22.947 & 11384976 & 1.53 & 16,17-Epoxy--pregna-5,7-diene-3,20-dione \\
\hline 9 & 44 & 23.155 & 5911270 & 0.79 & Lycopene \\
\hline 10 & 47 & 23.741 & 944846 & 0.13 & Nandrolone \\
\hline 11 & 48 & 23.826 & 7781038 & 1.05 & Pregnenolone \\
\hline 12 & 53 & 24.813 & 4571908 & 0.61 & Retinol, acetate \\
\hline 13 & 54 & 25.194 & 5044584 & 0.68 & Retinol, acetate \\
\hline 14 & 55 & 25.309 & 19261965 & 2.59 & 3,5-di-tert-Butyl-4-hydroxyphenylpropionic acid \\
\hline 15 & 56 & 25.663 & 41680714 & 5.6 & Retinol, acetate \\
\hline 16 & 59 & 26.618 & 12752988 & 1.71 & Ergosterol, acetate \\
\hline 17 & 62 & 27.504 & 26255142 & 3.53 & $15,17,19,21$-Hexatriacontatetrayne \\
\hline 18 & 63 & 27.751 & 14701154 & 1.98 & 7,11-Dihydroxyprogesterone \\
\hline 19 & 64 & 28.07 & 4145630 & 0.56 & Simvastatin \\
\hline 20 & 65 & 28.599 & 10449890 & 1.4 & Simvastatin \\
\hline 21 & 67 & 29.573 & 37326707 & 5.02 & Tanshinon II \\
\hline 22 & 68 & 29.882 & 11316491 & 1.52 & Pregna-4,16-diene-3,20-dione \\
\hline 23 & 69 & 30.026 & 10834880 & 1.46 & Corticosterone 21 -acetate \\
\hline 24 & 70 & 30.118 & 6277371 & 0.84 & Anthraegostatrine \\
\hline 25 & 71 & 30.249 & 5590219 & 0.75 & Phorbol 12,13,20-triacetate \\
\hline 26 & 72 & 30.525 & 4545773 & 0.61 & Retinol \\
\hline 27 & 73 & 31.089 & 15040232 & 2.02 & Retinol \\
\hline 28 & 74 & 31.325 & 23239899 & 3.12 & Ergosterol, acetate \\
\hline
\end{tabular}



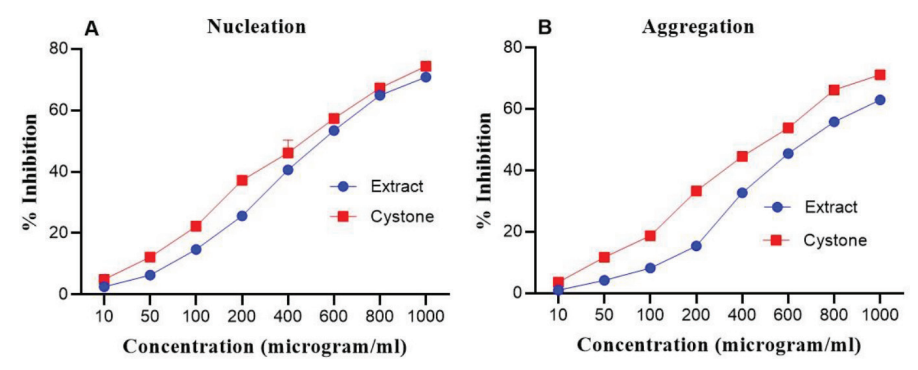

Figure 1: (A) nucleation assay and (B) aggregation assay.

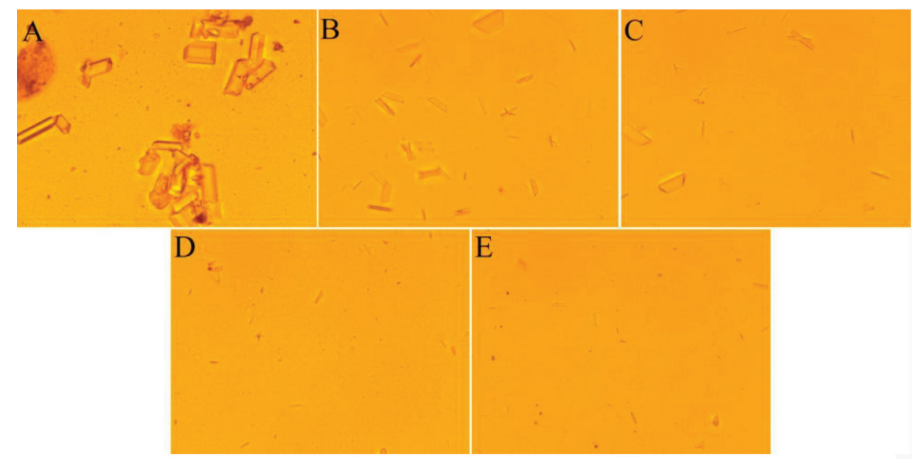

Figure 2: Light microscopic image of (A) control (without inhibitor), (B) EECB at $400 \mu \mathrm{g} / \mathrm{ml}$, (C) Cystone at $400 \mu \mathrm{g} / \mathrm{ml}$, (D) EECB at $1000 \mu \mathrm{g} / \mathrm{ml}$, (E) Cystone at $1000 \mu \mathrm{g} / \mathrm{ml}$.
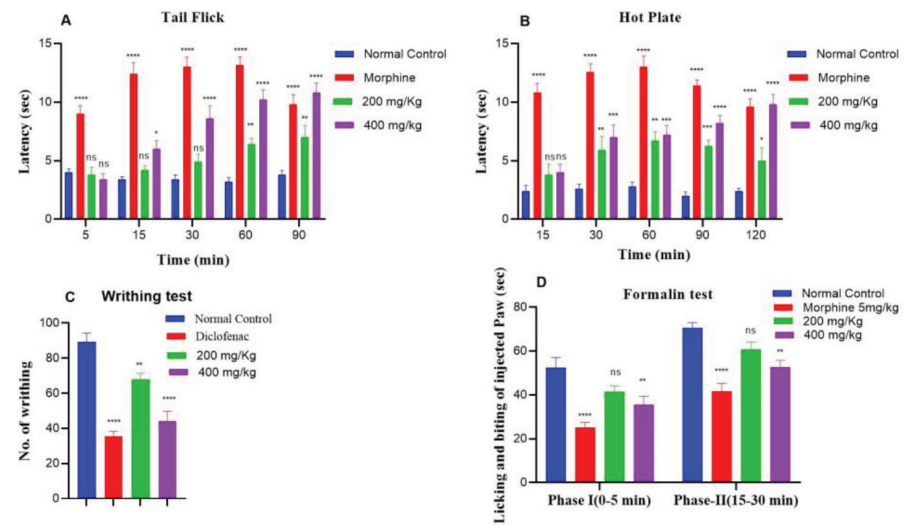

Figure 3: Effect of EECB on Tail flick test (A), Eddy's hot plate (B), writhing test (C), formalin test (D). $n=5$; mean $\pm \mathrm{SEM}$; ${ }^{\text {ss }} P>0.05$; ${ }^{*} P<0.05$; ${ }^{* *} P<0.01$; ${ }^{* * *}$ $P<0.001 ; * * * * P<0.0001$ compared with normal control.

as compared to the control group. EECB at dose of $400 \mathrm{mg} / \mathrm{kg}$ showed a significantly $(P<0.05$ to $P<0.0001)$ increase in urinary $\mathrm{Na}^{+}, \mathrm{Cl}^{-}$excretion, and non-significant $(P>0.05)$ in urinary $\mathrm{K}^{+}$excretion as compared with the normal control group (Table 2).

\section{DISCUSSION}

Extraction of C. bunducella seed were performed in ethanol (95\%) based on literature studies stating that ethanol (95\%) can offer superior extraction results for phenolic like chemicals because it dissolves the most polar and non-polar compounds. GC-MS analysis of EECB identified the presence of Vitamin E, steroidal ring containing compounds and hydrocarbons which may responsible for its pharmacological action.

\section{A Carragenan Induced Paw Edema}

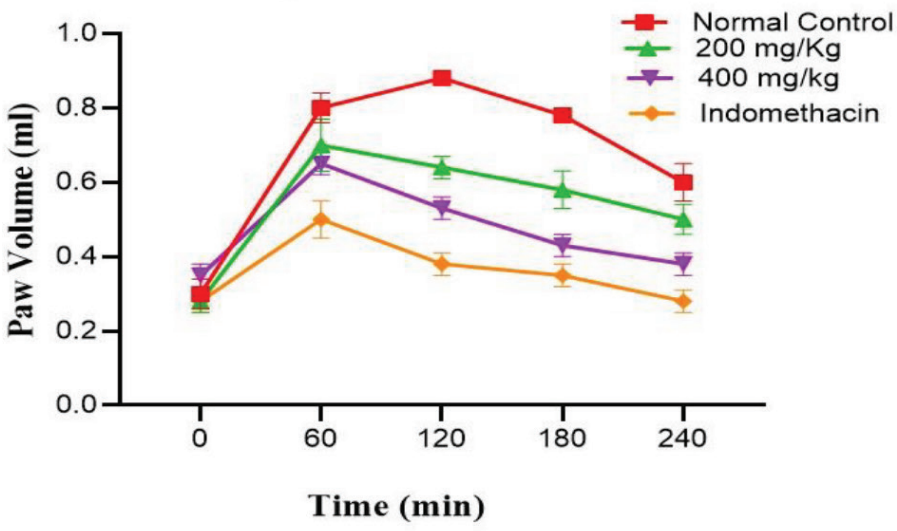

B Formalin Induced Paw Edema
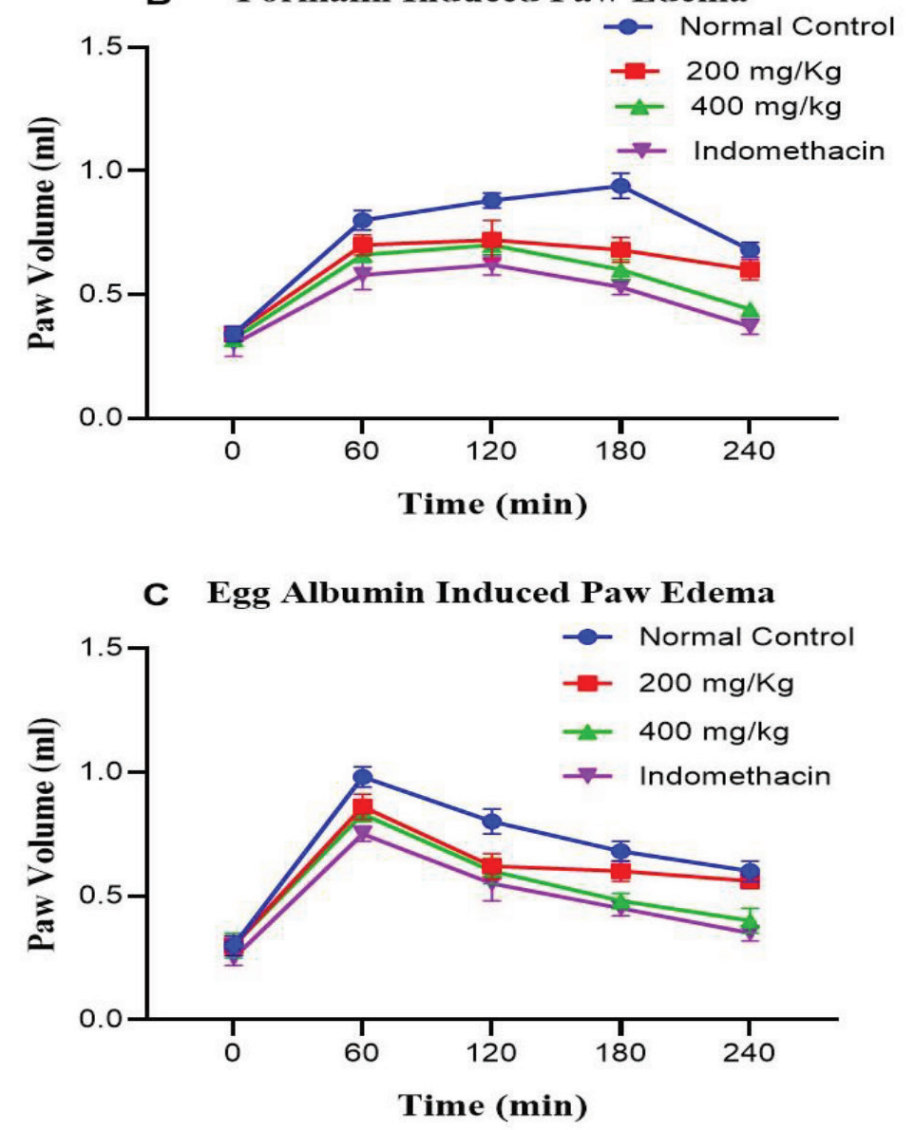

Figure 4: Effect of EECB on carrageenan model (A), formalin model (B), egg albumin model (C). $n=5$; mean \pm SEM.

Several researchers have reported that oxidative stress or free radical generation is increased with urinary supersaturation of oxalate which causes damage to epithelial cells. These damaged cells may work as binding surfaces or receptors for oxalate which promote the formation of the nucleus for urolithiasis. ${ }^{26-28}$ Antioxidants could be used in preventing the formation of the intrapapillary calcifications which is induced by oxidative stress that lead to papillary calculi formation. ${ }^{28}$ By treating renal epithelial cells with antioxidants we showed through in-vitro studies that EECB could be used as an agent for prevention of urolithiasis.

After $60 \mathrm{~min}$ of incubation, cystone showed the highest nucleation inhibition of $74.35 \pm 0.48 \%$ at $1000 \mu \mathrm{g} / \mathrm{ml}$, which was nearly similar to 
Table 2: Effect of extract on urine excretion in rats for $5 \mathrm{hr}$ after treatment.

\begin{tabular}{|c|c|c|c|c|c|c|c|c|c|c|}
\hline \multirow[t]{3}{*}{ Treatment } & \multicolumn{5}{|c|}{ Volume of Urine (ml) } & \multirow{2}{*}{\multicolumn{3}{|c|}{ Concentration of ions (meq/l) }} & \multirow{3}{*}{\multicolumn{2}{|c|}{$\begin{array}{c}\text { Saluretic } \\
\mathrm{Na} / \mathrm{K}\end{array}$}} \\
\hline & & & & & & & & & & \\
\hline & $1 \mathrm{hr}$ & $2 \mathrm{hr}$ & $3 \mathrm{hr}$ & $4 \mathrm{hr}$ & $5 \mathrm{hr}$ & $\mathrm{Na}+$ & $\mathrm{K}+$ & $\mathrm{Cl}-$ & & \\
\hline Control $10 \mathrm{ml} / \mathrm{kg}$ & $\begin{array}{c}0.59 \pm \\
0.1\end{array}$ & $1.4 \pm 0.19$ & $\begin{array}{c}2.3 \pm \\
0.17\end{array}$ & $\begin{array}{c}3.2 \pm \\
0.22\end{array}$ & $\begin{array}{c}3.98 \pm \\
0.1\end{array}$ & $\begin{array}{c}109.2 \pm \\
2.29\end{array}$ & $\begin{array}{c}60.6 \pm \\
3.91\end{array}$ & $\begin{array}{c}140.2 \pm \\
3.43\end{array}$ & 0.83 & 1.80 \\
\hline Furosemide $10 \mathrm{mg} / \mathrm{kg}$ & $\begin{array}{l}2.24 \pm \\
0.11^{\text {stat }}\end{array}$ & $\begin{array}{c}3.94 \pm \\
0.20^{\star * * *}\end{array}$ & $\begin{array}{c}5.5 \pm \\
0.24^{\star * * *}\end{array}$ & $\begin{array}{c}7.2 \pm \\
0.09^{* * * *}\end{array}$ & $\begin{array}{c}8.64 \pm \\
0.13^{* * * *}\end{array}$ & $\begin{array}{c}153.2 \pm \\
3.98^{* * * *}\end{array}$ & $\begin{array}{l}77.8 \pm \\
2.85^{* *}\end{array}$ & $\begin{array}{c}165.8 \pm \\
2.65^{* * * *}\end{array}$ & 0.72 & 1.97 \\
\hline Extract $200 \mathrm{mg} / \mathrm{kg}$ & $\begin{array}{c}0.74 \pm \\
0.14^{\mathrm{ns}}\end{array}$ & $\begin{array}{l}1.56 \pm \\
0.12^{\mathrm{ns}}\end{array}$ & $\begin{array}{l}2.5 \pm \\
1.2^{* *}\end{array}$ & $\begin{array}{c}3.6 \pm \\
0.11^{* *}\end{array}$ & $\begin{array}{c}4.78 \pm \\
0.12^{* * * *}\end{array}$ & $\begin{array}{l}127.8 \pm \\
3.93^{* *}\end{array}$ & $\begin{array}{l}64.2 \pm \\
2.92^{\text {ns }}\end{array}$ & $\begin{array}{l}146 \pm \\
3.38^{\text {ns }}\end{array}$ & 0.76 & 1.99 \\
\hline Extract $400 \mathrm{mg} / \mathrm{kg}$ & $\begin{array}{c}0.46 \pm \\
0.07^{\mathrm{ns}}\end{array}$ & $\begin{array}{c}1.7 \pm 0.17 \\
* * *\end{array}$ & $\begin{array}{c}2.74 \pm \\
0.19^{\star * * *}\end{array}$ & $\begin{array}{c}3.8 \pm \\
0.13^{* * * *}\end{array}$ & $\begin{array}{c}4.88 \pm \\
0.32^{\star * * *}\end{array}$ & $\begin{array}{c}136.6 \pm \\
2.64^{\star * * *}\end{array}$ & $\begin{array}{l}67.4 \pm \\
3.87^{\mathrm{ns}}\end{array}$ & $\begin{array}{c}152.8 \pm \\
4.57^{*}\end{array}$ & 0.75 & 2.03 \\
\hline
\end{tabular}

$\mathrm{N}=5$; mean $\pm \mathrm{SEM}$; ${ }^{\text {ns }} P>0.05 ;{ }^{*} P<0.05,{ }^{* *} P<0.01,{ }^{* * *} P<0.001,{ }^{* * * *} P<0.0001$ vs saline (control $10 \mathrm{ml} / \mathrm{kg}$, p.o).

the effect of EECB $(70.86 \pm 1.23 \%$ at $1000 \mu \mathrm{g} / \mathrm{ml})$. In aggregation assay, cystone had $71.18 \pm 152 \%$ of inhibition while the extract only had 62.95 $\pm 4.11 \%$ of inhibition at $60 \mathrm{~min}$. The increasing concentration of EECB had inhibited the calcium oxalate crystal growth in both nucleation and aggregation assay.

The anti-nociceptive effect of EECB was evaluated by chemical (formalin and acetic acid) and thermal models (Eddy's hot plate and tail-flick) of nociception. The formalin test has been divided into two phases. In first phase, substance " $\mathrm{P}$ " is released by direct stimulation of the sensorial C-fibers. The second phase is mediated by the increased level of PG, stimulation of COX, and release of nitric oxide. Two phases of pain response can be used to clarify the probable mechanism of antinociceptive. Centrally acting drugs prevent both phases of pain (such as opioids), whereas peripheral acting drugs only inhibit the second phase (inhibit COX activity, such as acetylsalicylic acid). ${ }^{21,23}$ The tail-flick test measures spinal anti-nociceptive action and the hot plate measures supra-spinal anti-nociceptive action. ${ }^{21,23}$ The antinociceptive effect in acetic acid, formalin, hot plate and tail-flick tests were altered by treating with EECB. These findings suggest that the anti-nociceptive activity of EECB is exhibited through central as well as peripheral mechanisms.

After $1 \mathrm{~h}$ of injection of phlogistic agent (carrageenan, egg-albumin, and formalin), the first phase (early phase) of edema is by the release of histamine and serotonin; and after $2 \mathrm{hr}$ to $4 \mathrm{hr}$ of injection of phlogistic agent, the second (later phase) is by release of bradykinin, protease and prostaglandin. ${ }^{21}$ In this study, EECB showed edema inhibition in both phases.

Standard drug furosemide enhances urine output and urinary excretion of $\mathrm{Na}^{+}, \mathrm{K}^{+}$, and $\mathrm{Cl}^{-}$by inhibiting $\mathrm{Na}^{+}-\mathrm{K}^{+}-2 \mathrm{Cl}^{-}$cotransport. ${ }^{24,29}$ This could suggest that the mechanism of EECB is not the same as the furosemide. EECB increases urine output and urinary excretion of $\mathrm{Na}^{+}, \mathrm{Cl}^{-}$which may be due to inhibition $\mathrm{Na}^{+}-\mathrm{Cl}^{-}$symport like thiazide. $\mathrm{Cl}^{-} / \mathrm{Na}^{+}+\mathrm{K}^{+}$ ratio was calculated and the ratios between 0.8 and 1.0 suggest that the carbonic anhydrase inhibition (CAI) mechanism is not applicable and as ratio decreases below 0.8 indicate slight to strong CAI. ${ }^{21,29}$ The $\mathrm{Cl} / \mathrm{Na}^{+}+\mathrm{K}^{+}$ratio for EECB at doses of $200 \mathrm{mg} / \mathrm{kg}, 400 \mathrm{mg} / \mathrm{kg}$, and furosemide showed a very weak Carbonic anhydrase inhibitory effect with values of $0.76,0.75$, and 0.72 , respectively. EECB at $400 \mathrm{mg} / \mathrm{kg}$ possesses significant diuretic activity which may be improve the antiurolithiatic effect by decreasing the supersaturation of stone-forming compound. ${ }^{30}$

\section{CONCLUSION}

It was confirmed that EECB possesses significant antiurolithiatic activity. The calcium oxalate crystals induce oxidative stress that leads to papillary calculi formation causing damage to epithelial cells, thus increasing oxalate crystal binding to cells and forming the nidus for urolithiasis. Antioxidants properties of EECB could be used in preventing oxidative stress and the formation of intra-papillary calcifications. The antiinflammatory and analgesic properties of EECB could be used in the prevention of inflammation and pain of damaged epithelial cells of nephrons, which are caused by intra-papillary calcifications. The diuretic activity of EECB helps in reducing supersaturation of calcium oxalate, which proves that EECB can be used as an effective antiurolithiatic drug.

\section{ACKNOWLEDGEMENT}

The authors would like to acknowledge the facility provided by the Department of Pharmacology, IMS, BHU, Varanasi, India.

\section{CONFLICT OF INTEREST}

The authors declare that there is no conflict of interest.

\section{REFERENCES}

1. Liu Y, Chen Y, Liao B, Luo D, Wang K, Li H, Zeng G. Epidemiology of urolithiasis in Asia. Asian J Urol. 2018;5(4):205-14. doi: 10.1016/j.ajur.2018.08.007,PMID 30364478.

2. Patel VB, Acharya N. Effect of Macrotyloma uniflorum in ethylene glycol induced urolithiasis in rats. Heliyon. 2020;6(6):e04253. doi: 10.1016/j.heliyon.2020. e04253, PMID 32637686

3. Ashok P, Koti BC, Vishwanathswamy AHM. Antiurolithiatic and antioxidant activity of Mimusops elengi on ethylene glycol-induced urolithiasis in rats. Ind J Pharmacol. 2010;42(6):380-3. doi: 10.4103/0253-7613.71925, PMID 21189910.

4. Kieley S, Dwivedi R, Monga M. Ayurvedic medicine and renal calculi. J Endourol. 2008;22(8):1613-6. doi: 10.1089/end.2008.0020, PMID 18620498.

5. Ata A, Gale EM, Samarasekera R. Bioactive chemical constituents of Caesalpinia bonduc (Fabaceae). Phytochem Lett. 2009;2(3):106-9. doi: 10.1016/j.phytol. 2009.02.002.

6. Jana K, Chatterjee K, Ali KM, De D, Bera TK, Ghosh D. Antihyperglycemic and antioxidative effects of the hydro-methanolic extract of the seeds of Caesalpinia bonduc on streptozotocin-induced diabetes in male albino rats. Pharmacogn Res. 2011;4(1):57-62.

7. Liu T, Wang M, Qi S, Shen X, Wang Y, Jing W, Yang Y, Li X, Gao H. Bioorganic Chemistry New cassane-type diterpenoids from kernels of Caesalpinia bonduc (Linn.) Roxb. Bioorg Chem. 2020;96:103573. doi: 10.1016/j.bioorg.2020.103573.

8. Gupta M, Mazumder UK, Kumar RS, Sivakumar T, Vamsi ML. Antitumor Activity and Antioxidant Status of Caesalpinia bonducella Against Ehrlich ascites Carcinoma in Swiss albino Mice. J Pharmacol Sci. 2004;94(2):177-84. doi: 10.1254/jphs.94.177, PMID 14978356. 
9. Datté JY, Traoré A, Offoumou AM, Ziegler A. Effects of leaf extract of Caesalpinia bonduc (Caesalpiniaceae) on the contractile activity of uterine smooth muscle of pregnant rats. J Ethnopharmacol. 1998;60(2):149-55. doi: 10.1016/s03788741(97)00144-X, PMID 9582005.

10. Datté JY, Yapo PA, Kouamé-Koffi GG, Kati-Coulibaly S, Amoikon KE, Offoumou AM. Leaf extract of Caesalpinia bonduc Roxb. (Caesalpiniaceae) induces an increase of contractile force in rat skeletal muscle in situ. Phytomedicine. 2004;11(2-3):235-41. doi: 10.1078/0944-7113-00292, PMID 15070178.

11. Bashir S, Gilani AH. Antiurolithic effect of Bergenia ligulata rhizome: an explanation of the underlying mechanisms. J Ethnopharmacol. 2009;122(1):106-16. doi: 10.1016/j.jep.2008.12.004, PMID 19118615.

12. Abu F, Mat Taib CN, Mohd Moklas MA, Mohd Akhir S. Antioxidant properties of crude extract, partition extract, and fermented medium of Dendrobium sabin Flower. Evid Based Complement Alternat Med. 2017;2017:2907219. doi: $10.1155 / 2017 / 2907219$.

13. Adebiyi OE, Olayemi FO, Ning-Hua T, Guang-Zhi Z. In vitro antioxidant activity, total phenolic and flavonoid contents of ethanol extract of stem and leaf of Grewia carpinifolia. Beni-Suef Univ J Bas Appl Sci. 2017;6(1):10-4

14. Khan MA, Rahman AA, Islam S, Khandokhar P, Parvin S, Islam MB, Hossain M, Rashid M, Sadik G, Nasrin S, Mollah MN, Alam AH. A comparative study on the antioxidant activity of methanolic extracts from different parts of Morus alba L. (Moraceae). BMC Res Notes. 2013;6:24. doi: 10.1186/1756-0500-6-24, PMID 23331970.

15. Mahdi-Pour B, Jothy SL, Latha LY, Chen Y, Sasidharan S. Antioxidant activity of methanol extracts of different parts of Lantana camara. Asian Pac JTrop Biomed. 2012;2(12):960-5. doi: 10.1016/S2221-1691(13)60007-6, PMID 23593576.

16. Xiao F, Xu T, Lu B, Liu R. Guidelines for antioxidant assays for food components. Food Front. 2020;1(1):60-9. doi: 10.1002/fft2.10.

17. Bawari S, Negi Sah AN, Tewari D. Antiurolithiatic activity of Daucus carota: an in vitro study. Pharmacogn J. 2018;10(5):880-4. doi: 10.5530/pj.2018.5.148.

18. Abu Zarin MA, Tan JS, Murugan P, Ahmad R. Investigation of potential antiurolithiatic activity from different types of Musa pseudo-stem extracts in inhibition of calcium oxalate crystallization. BMC Complement Med Ther. 2020;20(1):317. doi: 10.1186/s12906-020-03113-0, PMID 33076892.

19. Sasikala V, Ramu S, Vijayakumari B. In vitro evaluation of Rotula aquatica Lour. for antiurolithiatic activity. J Pharm Res. 2013;6(3):378-82.

20. Bukhari IA, Gilani AH, Meo SA, Saeed A. Analgesic, anti-inflammatory and antiplatelet activities of Buddleja crispa. BMC Complement Altern Med. 2016;16:79. doi: 10.1186/s12906-016-1021-4, PMID 26911873.
21. Vogel HG, Vogel WH, Schölkens BA, Sandow J, Müller G, Vogel WF. Drug discovery and evaluation: pharmacological assays. 3rd ed. Berlin, Germany: Springer-Verlag; 2007.

22. Zeb A, Ahmad S, Ullah F, Ayaz M, Sadiq A. Anti-nociceptive activity of ethnomedicinally important analgesic plant Isodon rugosus Wall. ex Benth: mechanistic study and identifications of bioactive compounds. Front Pharmacol. 2016:7:200 doi: 10.3389/fphar.2016.00200, PMID 27458379.

23. Rezaee-AsI M, Sabour M, Nikoui V Ostadhadi S, Bakhtiarian A. The study of analgesic effects of Leonurus cardiaca L. in mice by formalin, tail flick and hot plate tests. Int Sch Res Not. 2014;2014:1-5. doi: 10.1155/2014/687697, PMID 687697.

24. Gasparotto A Jr, Boffo MA, Lourenço EL, Stefanello ME, Kassuya CA, Marques MC Natriuretic and diuretic effects of Tropaeolum majus (Tropaeolaceae) in rats. J Ethnopharmacol. 2009;122(3):517-22. doi: 10.1016/j.jep.2009.01.021, PMID 19429322.

25. Ghelani H, Chapala M, Jadav P. Diuretic and antiurolithiatic activities of an ethanolic extract of Acorus calamus L. rhizome in experimental animal models. J Trad Complement Med. 2016;6(4):431-6. doi: 10.1016/j.jtcme.2015.12.004, PMID 27774431.

26. Ceban E, Banov P, Galescu A, Botnari V. Oxidative stress and antioxidant status in patients with complicated urolithiasis. J Med Life. 2016;9(3):259-62. PMID 27974930.

27. Kizivat T, Smolic M, Maric I, Tolušic Levak M, Smolic R, Bilic Curcic I, Kuna L, Mihaljevic I, Vcev A, Tucak-Zoric S. Antioxidant pre-treatment reduces the toxic effects of oxalate on renal epithelial cells in a cell culture model of urolithiasis. Int J Environ Res Public Health. 2017;14(1):109. doi: 10.3390/ijerph14010109, PMID 28125004

28. Marhoume FZ, Aboufatima R, Zaid Y, Limami Y, Duval RE, Laadraoui J, Belbachir A Chait A, Bagri A. Antioxidant and polyphenol-Rich ethanolic Extract of Rubia tinctorum L. Prevents Urolithiasis in an ethylene glycol Experimental Model in Rats. Molecules. 2021;26(4):1005. doi: 10.3390/molecules26041005, PMID 33672875.

29. Hailu W, Engidawork E. Evaluation of the diuretic activity of the aqueous and $80 \%$ methanol extracts of Ajuga remota Benth (Lamiaceae) leaves in mice. BMC Complement Altern Med. 2014;14:135. doi: 10.1186/1472-6882-14-135, PMID 24720845.

30. Siddiqui WA, Shahzad M, Shabbir A, Ahmad A. Evaluation of anti-urolithiatic and diuretic activities of watermelon (Citrullus lanatus) using in vivo and in vitro experiments. Biomed Pharmacother. 2018;97:1212-21. doi: 10.1016/j. biopha.2017.10.162, PMID 29145146.

Article History: Submission Date : 14-07-2021; Revised Date : 18-08-2021; Acceptance Date : 04-09-2021.

Cite this article: Kumar A, Nandi MK, Kumar B, Kumar A, Kumar R, Singh AK, Singh M. Antiurolithiasis, Antioxidant, Anti-inflammatory, Analgesic, and Diuretic Activity of Ethanolic Extract of Seeds of Caesalpinia bonducella. Int. J. Pharm. Investigation. 2021;11(3):306-11. 